\title{
Climate Resilience and Policy Transfer in Semarang City, Indonesia
}

\author{
Yulia Yulia \\ https://orcid.org/0000-0003-2634-7734 \\ Urban Planner and Designer, Independent Scholar, Indonesia \\ Reza Arlianda \\ https://orcid.org/0000-0002-2838-4742 \\ Architect, Independent Scholar, Indonesia
}

\begin{abstract}
Cities around the world are facing tremendous challenges due to climate change. Tropical cities are significantly impacted by temperature increases, higher than average global rising sea levels, and extreme weather events. In the tropical Asia-Pacific region effects from the El Niño-Southern Oscillation are especially severe, which, in turn, cause disasters such as floods and droughts. Climate change requires cooperation from actors across geopolitical borders to respond to the problem collectively, which involves global networks in the exchange of climate mitigation policies and adaptation plans through a process of policy transfer. This paper examines the processes of policy transfer between the tropical coastal city of Semarang in Indonesia and its global networks in the '100 Resilient Cities', and the 'Water as Leverage' programs. The paper analyses interviews with actors and stakeholders from these two programs, and examines key factors that determine the success of the climate change policy transfer in Semarang City.
\end{abstract}

Keywords: policy transfer, climate resilience, 100 Resilient Cities, Water as Leverage, tropical cities, climate change, urbanisation

eTropic: electronic journal of studies in the tropics publishes new research from arts, humanities, social sciences and allied fields on the variety and interrelatedness of nature, culture, and society in the tropics. Published by James Cook University, a leading research institution on critical issues facing the worlds' Tropics. Free open access, Scopus Listed, Scimago Q2. Indexed in: Google Scholar, DOAJ, Crossref, Ulrich's, SHERPA/RoMEO, Pandora. ISSN 1448-2940. Creative Commons CC BY 4.0 free to download, save and reproduce. To cite, include: Author(s), Title, eTropic, volume, issue, year, pages and DOI: http://dx.doi.org/10.25120/etropic.19.2.2020.3767 
eTropic 19.2 (2020) Special Issue: Sustainable Tropical Urbanism

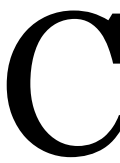

limate change is a global phenomenon with impacts that have been experienced by cities worldwide. Tropical cities experience significance impacts from temperature increases and higher than average global sea level rise, while in the tropical Asia-Pacific region severe effects from the El Niño-Southern Oscillation cause extreme weather events which result in disasters such as floods and droughts (Lundberg, 2020). Climate change phenomena have pushed city governments to seek innovative solutions and creative ways to engage city planning as traditional practices reach their limits. Cross-theme and cross-boundary collaborations have become prevalent in climate change governance as cities strive to develop comprehensive responses to climate change. Collaborations are needed in the form of cross-sectorial collaborations, stakeholder collaborations, local to national government collaborations, and city-to-city collaborations. City-to-city collaborations can be undertaken between cities within the same country, between cities in different countries, and even the involvement of cities in global networks working collaboratively on a particular topic or towards a specific goal.

These collaborations allow cities to learn from each other regarding best practices, methodologies, technologies, strategies, regulations and so on. More specifically, such collaborations may involve cities in the exchange of knowledge and expertise on a particular topic or issue. As a result of this exchange, a policy, strategy, program, ideology or other arrangement that has been used in one time and place, is (re)used in another. This process is widely known as the policy transfer process (Minkman et al., 2019).

The policy transfer process is now common practice in contemporary policy making (Dolowitz \& Marsh, 2000, pp. 5-23), and is increasing as cities collaborate with each other or join international networks to work together on a particular issue. Currently there are many established international networks that focus on the specific topic of developing climate-resilient cities, for example: 100 Resilient Cities, Water as Leverage, The ASEAN Climate Resilient Network, Asian Cities Climate Change Network (ACCRN), Global Resilience Network, and many more. Transfer processes that are carried out under an international network have various formats and set-ups. Some networks also provide experts in relevant fields to help their members develop strategies towards a climate-resilient city. Even though this transfer process seems feasible and possible, many programs encounter impasses in the transfer process. The process itself is complicated and involves several elements in order to be successful. Success involves enabling cities to grasp the value and the content of the transfer and adapt or adopt these elements into local practices that suit local cultural and environmental landscapes and capabilities. 
eTropic 19.2 (2020) Special Issue: Sustainable Tropical Urbanism

This paper analyses the complexity of policy transfer processes in the context of contemporary policy making in response to climate change. The paper further examines what constitutes a successful policy transfer process by using Semarang, a tropical city located in Indonesia, as a case study. Semarang is identified as a suitable case study due to its hydro-meteorological issues affected by both global and tropical Asia-Pacific climate change phenomena and its coastal and riverine geography, and the city's recent involvement in two international networks: 100 Resilient Cities (100RC) and Water as Leverage (WaL). These two networks have helped the Semarang City Government in the formulation of a climate-resilient strategy and action plan.

The authors hope this paper can contribute to both academic and practical spheres regarding the articulation and implementation of international collaborations between cities. The paper will be of particular interest to international organisations that initiate, and the stakeholders involved in, international collaborations.

\section{Theoretical Framework of the Policy Transfer Process}

In Indonesia, the policymaking process is structured according to an established hierarchical pattern which ranges from the smallest administrative government level of the neighbourhood and village, to its respective sub-district, district/city, and provincial levels, up to the national scale (Republik Indonesia, 2004). The local term for the policymaking process is Musrenbang. This is a deliberative policy making process that is held at stakeholder forums at each administrative level with the aim of synchronising all development plans while simultaneously undertaking the threedevelopment planning process approach, which is: participatory, bottom-up, and topdown (Datta, et al., 2011). Within this framework of deliberation, multiple actors and stakeholders engaged in policy transfer can present their agenda, whether they be from public institutions, for instance politicians, civil servants or state officials; nongovernment agents, including business advocates, think-tanks, the general public and professionals; or from international networks (Stone, 2004).

The policy transfer process in Indonesia is not new; but rather, is considered a common practice in the contemporary policy making process. In the case of climate resilient policies in Semarang, a variety of examples of the policy transfer process have already been established which involve diverse actors and intentions. These include: an agency for a poverty reduction program that introduces a triple helix policy to various economic actors (Amni \& Diyah, 2018); international networks which transfer the climate resilience policy through negotiating systematic adaptation through institutional pathways (Lassa, J.A., 2019); and specific spatial intervention programs which emulate Dutch polder and water board systems with the intention of 
eTropic 19.2 (2020) Special Issue: Sustainable Tropical Urbanism

solving Semarang's flood issues (Peters, 2012). All these efforts manifest in particular changes with various degrees of policy transfer successfulness and lessons learned.

The following section elaborates on the concept of the policy transfer process, including what, why and how this process is conducted, and explores the elements and variables that are required to achieve any successful policy transfer.

\section{Policy Transfer Processes in the Perspective of Climate Change}

Rapid urbanisation, combined with the challenges of climate change, renders the usual urban development strategies inadequate to cope with these changes and to coordinate comprehensive responses to climate challenges (Wright \& Nyberg, 2017). The structure for regulatory guidance that manages all aspects of organisational and economic activity addressing climate change requires a stronger coordinated effort from the established public institutions. At the same time, an understanding of climate change at all government levels is required to counteract a lack of recognition towards climate change policy and programs in Indonesian cities by district authorities, which creates a general perception that climate change adaptation is a new issue and that only a few actors can articulate its importance (Sutarto \& Jarvie, 2012).

Resolving global scale issues such as climate change demands more than fragmented responses from discordant authorities. The sheer quantity of resources needed and the political commitment to tackle specific problems and their climatic causes requires collective understanding from numerous stakeholders both in and beyond the administrative order. Thus the scale of urban challenges under rapid growth and the impact of climate change has stimulated the establishment of international collaborations between multiple actors to seek solutions and agreements in various forms: whether in the form of the global United Nations agreement and the collective movement of the Sustainable Development Goals (SDG) (Griggs et al., 2013); the municipal relations of sister cities (De Villiers et al., 2007); or the establishment of an international network of policy experts (Stone, 2001). When such policy processes result in similar strategies, approaches, programs, or regulations to address various specific goals and problems, it is an indication that the policy transfer process has happened.

The process of transferring inspiration, best practices, and experiences between actors which leads to the formulation of a policy is lengthy and thus necessitates time. Any policy transfer process can be seen as a social process of change because it stimulates policymakers to reflect upon current approaches, strategies, programs and regulations; assess how effective these existing attempts to solve the problem are; and eventually involves rethinking strategic ideas that are received from the sender in 
eTropic 19.2 (2020) Special Issue: Sustainable Tropical Urbanism

order to reformulate the existing strategy to suite local contexts (Minkman et al., 2019). Aligned with this, the policy transfer process also acts as an iterative process, necessitating the adaptation or adoption of approaches, strategies, programs or regulations from different places and periods of time to new circumstances (Dolowitz \& Marsh, 2000).

It has been argued that policy transfer works better if it is initiated by the recipient who recognises the problem independently; compared to top-down transfer by policy change promoters (Stead, 2012). Also noted is that the introduction of climate change strategies within a developing country require more background transfer processing, such as mainstreaming efforts and policy adaptation (Mertz et al., 2009). While the fast development of information access and communication technology further enables knowledge exchange between policy stakeholders; the burden for international cooperation in handling climate change is dependent on the successfulness of the process of policy transfer.

\section{Policy Transfer in Spatial Planning and Urban Design}

Based on Indonesian Law no. 26/2007, any finalised regulation and development project would produce spatial planning outcomes that must draw on each governmental administrative level from the district, regional, provincial, up to the national scale (Hasyim et al., 2016). However, despite being based on the legal framework and supported by regional regulation, the ineffective enforcement of spatial planning (Nugroho \& Sugiri, 2009) has attracted the further participation of spatial planners, designers, scholars, and policy entrepreneurs in the formulation of plans and their contents. This has led to the appearance of two international networks, the 100 Resilient Cities and the Water as Leverage, that specifically address climate change policy and programs in Semarang within the scope of spatial planning and urban design discourses. Using the two networks as case studies, this paper tries to unfold the overlay between the policy transfer process and its further implementation in spatial planning.

The discourse about policy transfer was initially examined by political scientists which established analytical tools and exploration from rationalist perspectives (Benson \& Jordan, 2012). However, recent analyses have critiqued the homogeneous nature of this earlier research and urge the diversification of the conversation. There is a wealth of intellectual currency that can be unfolded through the investigation of policies' mobility, circulation, reformulation, and convergence from multidisciplinary perspectives. McCann and Ward (2012) note the importance of additional research from different academic backgrounds that have a direct or indirect influence in policymaking in order to expand the topic of policy transfer. In this paper, we define 
eTropic 19.2 (2020) Special Issue: Sustainable Tropical Urbanism

policy transfer from the spatial planner and designer perspective as the process whereby city policy-makers (and associated decision-makers) exchange urban form designs and spatial strategies in order to tackle various circumstances and problems within their cities.

In the field of spatial planning which requires actors to collect analyses, emulations, and assemblages of policies and spatial models from different cities as its inspirational sources, planners are required to undertake a vast examination of the transfer of best practices as part of their policy formulation. Through analysing structured information regarding a successful practice in tackling a similar problem, policymakers and spatial planners across cultural differences and geographical localities share examples of good practices in the policy transfer and lesson-drawing framework (Vettoretto, 2009). In so doing, spatial planning offers an important site from which to examine the unfolding and the underlying logic and mechanisms of policy transfer processes - and their success or failure.

\section{Policy Transfer Success and Failure}

The process of policy transfer is complex and can lead to an impasse. The inclusion of consultants and experts from various networks does not rely solely on the innovation or idea; rather, the process of negotiation, compromise, and persuasion from the transfer agent plays an important role in influencing the receiver and defining the success of the policy transfer (Stone, 2001). Prevalent literature of policy transfer defines the degree of success of the policy transfer process based on how the transfer materials are accepted and followed-up by the recipient. If the recipient adapts or adopts the value or approach or any other element that is transferred, then the process remains successful. However, in numerous cases, the policy transfer process cannot happen or meets an impasse due to several conditions: the unsavoury reputation of the transfer agent or the sender, exclusive and limited transfer content to a particular context, and the absence of willingness or motivation from the receiver (Minkman et al., 2019).

Apart from these three aspects, the failure of the policy transfer process can also be examined from the perspective of the process itself. Dolowitz and Marsh (2000) explained three reasons why a policy transfer process could fail: the transfer process is uninformed, it is incomplete, or it is insufficient. Uninformed transfer refers to a condition where the receiver does not have sufficient information regarding the content of the transfer and how it operates in its original place. Incomplete transfer is when a transfer process has been running, but the process is missing several elements in its transfer location that made the policy successful in its place of origin. Lastly, insufficient transfer refers to a condition in which the transfer agents do not pay 
eTropic 19.2 (2020) Special Issue: Sustainable Tropical Urbanism

attention to the local context of the receiver and the ways in which that context varies from the transfer agent's place of origin. This condition can lead to rejection and failure during the middle of the process.

\section{Analysing Key Success Factors in the Policy Transfer Process}

A common starting point in analysing policy transfer can be established by trying to answer three simple questions. Why might the policy transfer happen? What is being transferred? And who is involved in the policy transfer process? The 'why' question reveals the motivation of both receiver and transfer actors in conducting the policy transfer process. The attempt to answer this question should also look into the degree of engagement that might vary from voluntary to coercive transfer characteristics. The 'what' question examines the object of the transfer, whether it is a goal, instrument, idea, approach, value, ideology or even negative lessons. Meanwhile, the 'who' question tries to identify the involved actors in the policy transfer process and also the set-up of the transfer process itself (Dolowitz \& Marsh, 1996).

Figure 1 Policy Transfer Framework

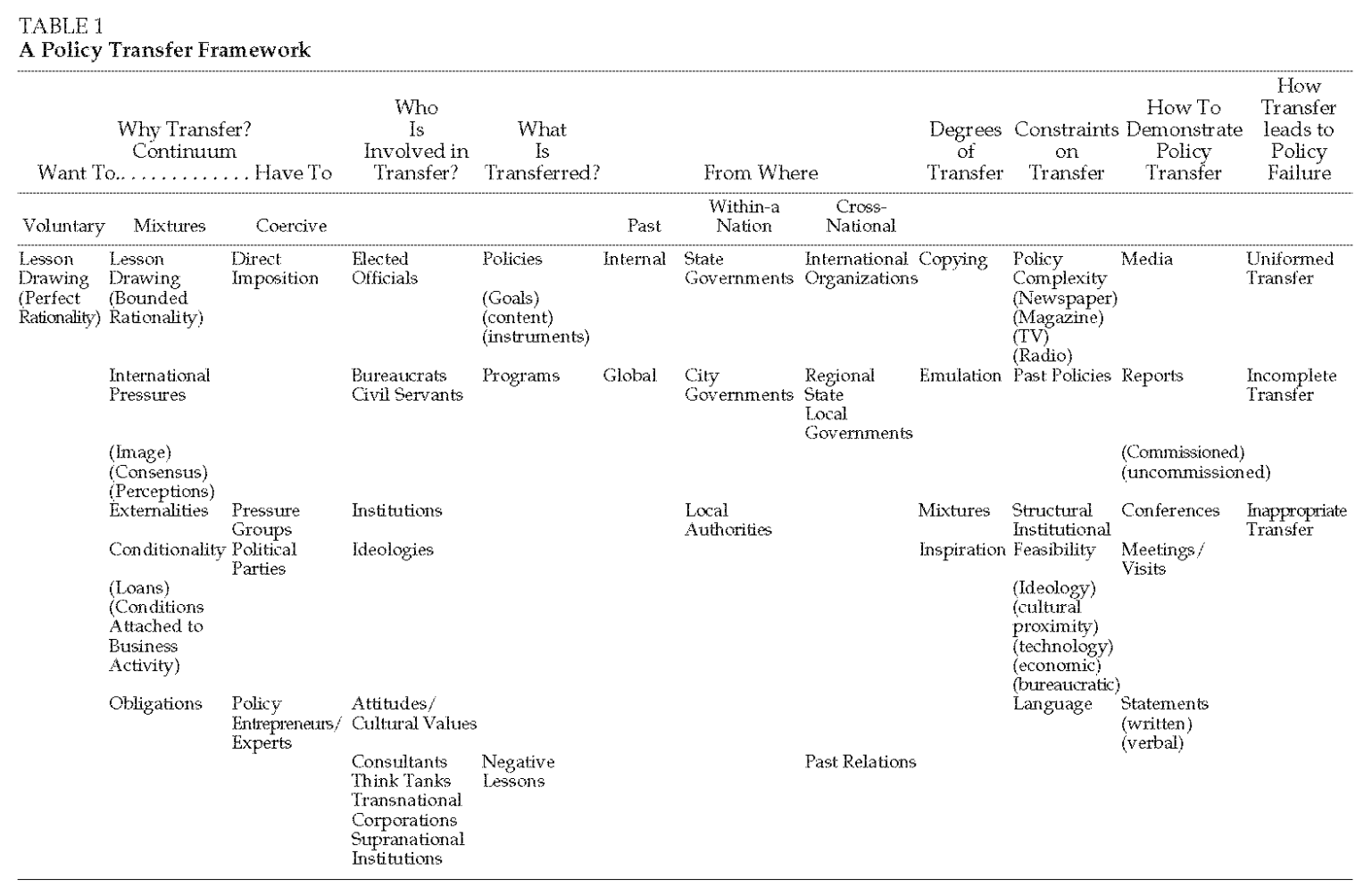

Source: Dolowitz and Marsh (2000).

Four years after the introduction of their three theoretical questions, Dolowitz and Marsh updated and compiled the variables into a policy transfer framework which included the further factors of: degree, constraints, and demonstration. Transfer 
eTropic 19.2 (2020) Special Issue: Sustainable Tropical Urbanism

degree refers to whether it is a process of copying or emulating; constraints of the transfer refers to barriers, whether in the institution, structure, ideology, or even language; and demonstration refers to the tools employed in the transfer, whether in meetings, conferences, or media (Dolowitz \& Marsh, 2000).

Based on the work of Dolowitz and Marsh, we have adapted the framework in order to analyse key success factors in the policy transfer process for the case study of Semarang City. This framework tries to examine the transfer process in a more comprehensive way through four clusters of key success factors, which not only examine the policy transfer process and its outcome, but also include motivational elements that initiated the process in the first place. These four clusters are: (1) motivation of policy transfer, (2) content of policy transfer, (3) policy transfer process and (4) results of the policy transfer process. Further explanation of each cluster can be found in the following Figure 2.

Figure 2 Conceptual Framework: Analysing Key Success Factors of the Policy Transfer Process

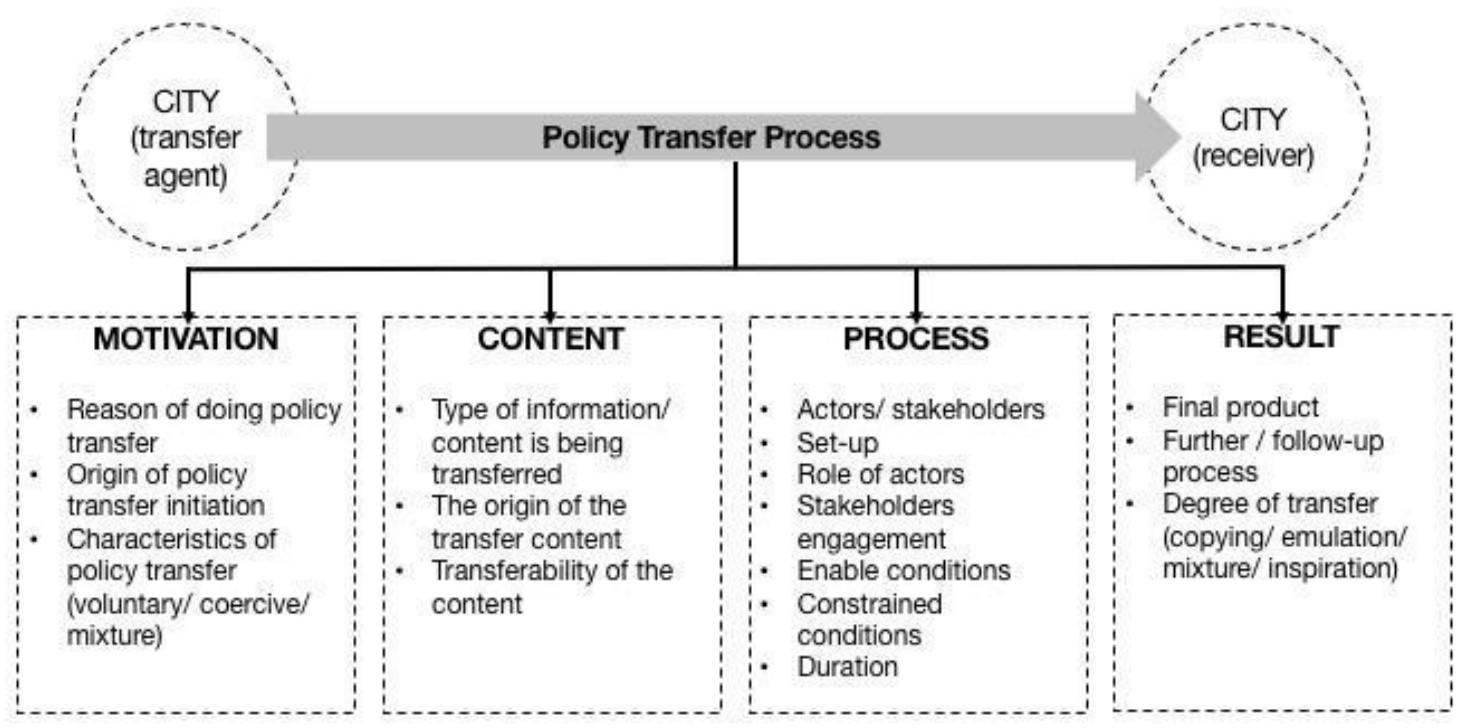

\section{Methodology}

The research methods that are used to answer the underlying question are desk research (secondary research) and interviews (primary research) as a means of qualitative research methodology to examine the two selected case studies. These methods were chosen based on the fact that the first case study happened in the earlier time period of 2013-2016, and thus examining the policy transfer process through public documents was necessary in order to give a background to the transfer process; however, in order to support the desk research, the authors also undertook 
several interviews with involved stakeholders to confirm emerging questions resulting from the desk research. The interviews were useful to close the information gap regarding the policy transfer process itself, which was not addressed in the documents. The second case study occurred recently and the authors were involved in the process. In this case, the authors directly experienced the whole process, but furthermore present the case in an objective way by including interviews with stakeholders. Both case studies will be presented in the Case Descriptions section below.

In the process of seeking answers to what makes a policy transfer process successful, the aforementioned conceptual framework (Figure 2) is tested by translating each of the four clusters of key success elements of the framework into simple and understandable questions for the interview respondents. All of the interview sessions were recorded and transcribed for further analysis. In the later Analysis section of this paper, each of the interview answers is examined and paired with the relevant elements and clusters. The Analysis results demonstrate important elements of each cluster that should exist towards a successful policy transfer process. In short, the answers are revealed based upon the clusters presented in the conceptual framework, and each cluster has a similar weight. This means that the order of presented clusters in this paper does not state the degree of importance of one cluster to another since each cluster received identical treatment during the research.

\section{The Context of Semarang City and its Climate Challenges}

Semarang is a port city located at the northern coast of Java island, the most populous island in Indonesia. This city also serves as the capital of Central Java province and one of the largest cities in the country after Jakarta (the capital of Indonesia), Surabaya, Medan and Bandung. In the realm of urbanisation, this city forms an agglomeration of the metropolitan area with its surrounding cities, namely Kedungsepur (an abbreviation of Kendal, Demak, Ungaran), Semarang Municipality, Salatiga, Semarang City, Purwodadi, and Grobogan. With an approximate area of only 373,30 square kilometres, Semarang is inhabited by more than 1.7 million people (statistics for 2017). This number can reach nearly 2 million people during the day due to commuting activities to the city (Central Bureau of Statistics, 2018). In terms of administration, Semarang is divided into 16 districts, as can be seen in Figure 3. Based on the statistics data in 2017, the highest population density is located in the northern part of the city in Gayamsari district (12.853 people/sqkm), followed by Semarang Selatan (or South Semarang) district (11.755 people/sqkm), and Candisari district (11.613 people/sqkm). 


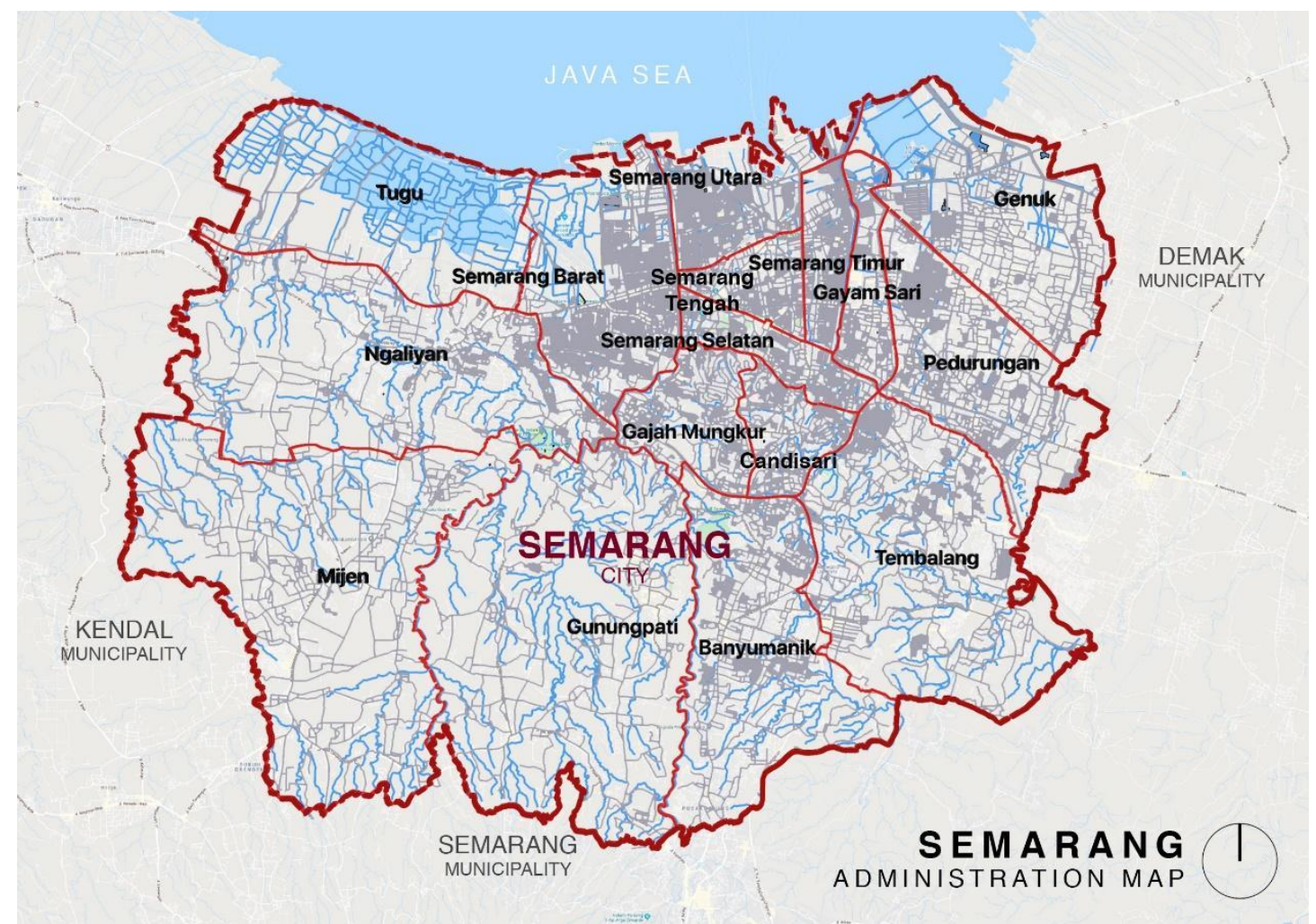

The city consists of 16 districts with the highest density located in the northern part of the city.

Based on its geographic location, Semarang can be classified as a coastal city. However, the topography of the city is quite varied with the southern part of the city located on a higher hill level compared with the northern plains. Mijen district is situated 300 meters above sea level and serves as the highest area in the city; however, the city centre (part of Semarang Tengah and Semarang Utara districts) is situated merely 1-2 metres above sea level. Due to this condition, Semarang is well-known for environmental issues such as flash floods, tidal floods, and landslides. Floods in Semarang involve a combination of environmental factors between sea level rise, land subsidence, coastal erosion and tidal movements. The recent growth in population, urbanisation, and high land prices amplifies the problems of the climate-related vulnerable area of the city (Harwitasari \& van Ast, 2011). These issues are worsened by the impact of climate change phenomenon, including the equatorial Asia-Pacific El Niño-Southern Oscillation which causes extreme weather, including heavy rains during the wet season and La Niña events, as well as droughts during the dry season and El Niño events (Lundberg, 2020). The impacted areas within the city can be seen in Figure 4 below. 


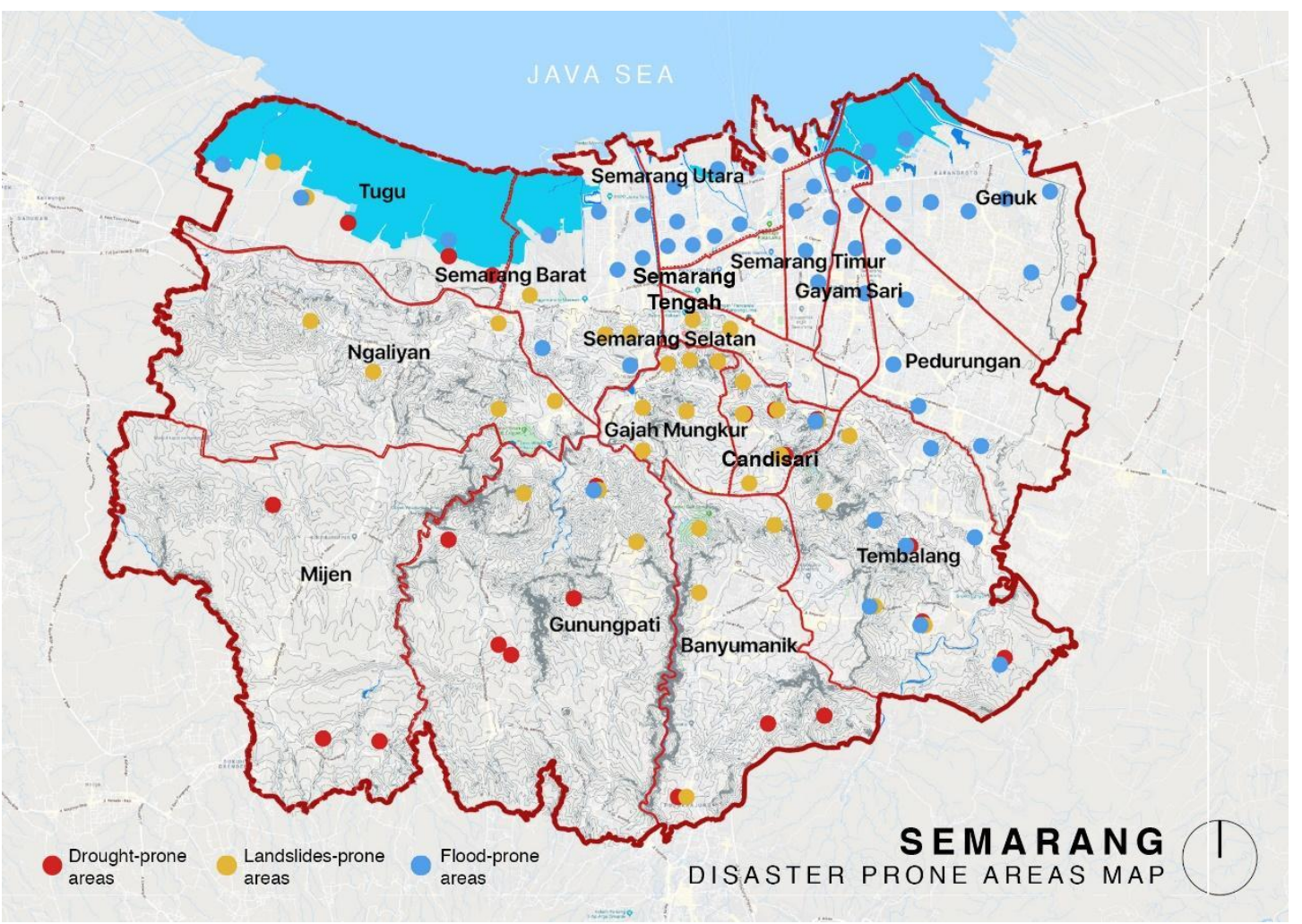

Source: Semarang Regional Disaster Management Office (BPBD Semarang).

In response to these challenges, Semarang City Government has been proactive. The city government employs coastal flood management practices consisting of two methodologies comprising both structural and non-structural interventions. The structural intervention is measured by the construction of flood ways, dykes, and drainage systems; while the non-structural approach is undertaken by setting up the institutional framework that provides support for hazard mitigation, planning guidelines, regulation, and intervention implementation (Marfai \& King, 2008). Several initiatives have been undertaken by the government to solve the city's climate related challenges, for example: (1) The construction of Banger Polder as part of flood management efforts through collaboration between the national government, Semarang City Government, and the Netherlands, (2) West Flood Canal revitalisation, also part of flood management efforts as well as providing public green open spaces for residents and (3) the Resilient Kampong program, which is aimed at preparing the residents of Semarang in case of natural disasters. This program is initiated and implemented by the Semarang Regional Disaster Management Office (BPBD Semarang). However, these extensive efforts undertaken exclusively by the government are considered inadequate and thus ineffective. It is believed that stakeholder and community participation is required in order to gain the necessary improvement in scale and success (Marfai \& King, 2008). 
eTropic 19.2 (2020) Special Issue: Sustainable Tropical Urbanism

Thus, in addition to the example initiatives cited above, the Semarang City Government has actively sought collaborations with both national and international partners to help the city design a more comprehensive plan to manage the impact of climate change. This is represented by the involvement of the city in two prestigious resilient city-focused global networks during the period of 2016-2019: the 100 Resilient Cities (100RC) and the Water as Leverage (WaL) programs. These two collaborations serve as the case studies for this paper.

\section{Case Descriptions}

Thus, this paper addresses what makes a policy transfer process successful by using two case studies situated in Semarang City. This section describes the two chosen case studies, 100 Resilient Cities (100RC) and Water as Leverage (WaL), as well as the involvement of Semarang City Government and the policy transfer process that happened as a result of the city's involvement in these two global networks.

\section{Case One: 100 Resilient Cities (100RC)}

\section{Brief Description of the Network}

100 Resilient Cities (100RC) was a program pioneered by the Rockefeller Foundation that aimed to assist cities worldwide in formulating an integrated city resilience strategy to cope with changes and challenges faced by the city. The members of this network vary, and comprise cities from any region around the globe. This program was created in 2013 and came to an end in 2019. It began working with the first group of 32 cities in its early initiation in 2013, the network added 35 more cities in 2014, and the final round of applications began May 2016 (100 Resilient Cities, 2019). The network gives its city members access to service providers and partners from various sectors (private, public and non-governmental sectors) who can help them develop and implement the resilience strategies. It also provides a platform for knowledge exchange as well as peer-to-peer learning and assistance. By joining this network, each city member has to show its commitment to creating a resilient city represented by its city resilience strategy as the output.

\section{What is being Transferred within the Network}

In the 100RC operation, the network transfers at least two things: the urban resilience paradigm and City Resilience Framework (CRF) as the basis for cities to formulate their strategies. In terms of resilient city understanding, 100RC uses the terms "shocks" and "stresses" to metaphorically illustrate the challenges faced by cities due 
to the global phenomenon of climate change. "Shocks" refers to an event that brings a severe impact to the city, such as natural disasters; while "stresses" refers to tensions experienced by the city that could lead to shocks if they are not properly taken care of, such as traffic jams, water crises and many more. Furthermore, the understanding of a resilient city, as formulated by 100RC, requires a comprehensive yet integrated approach of all urban development aspects: physical, social, economic and governance. This understanding is represented by the City Resilience Framework (CRF) that serves as a base used by each city member in developing their city resilience strategy (Figure 5 below).

The City Resilience Framework (CRF), which serves as the main tool in developing a city resilience strategy, is the result of a collaboration between the Rockefeller Foundation (as the initiator) with a global design firm. The CRF is illustrated in a circle chart and consists of four dimensions: health and wellbeing, economy and society, infrastructure and environment, as well as leadership and strategy. These four dimensions are considered essential systems of a city in terms of building its resilience.

Figure 5 The City Resilience Framework (CRF) Wheel.

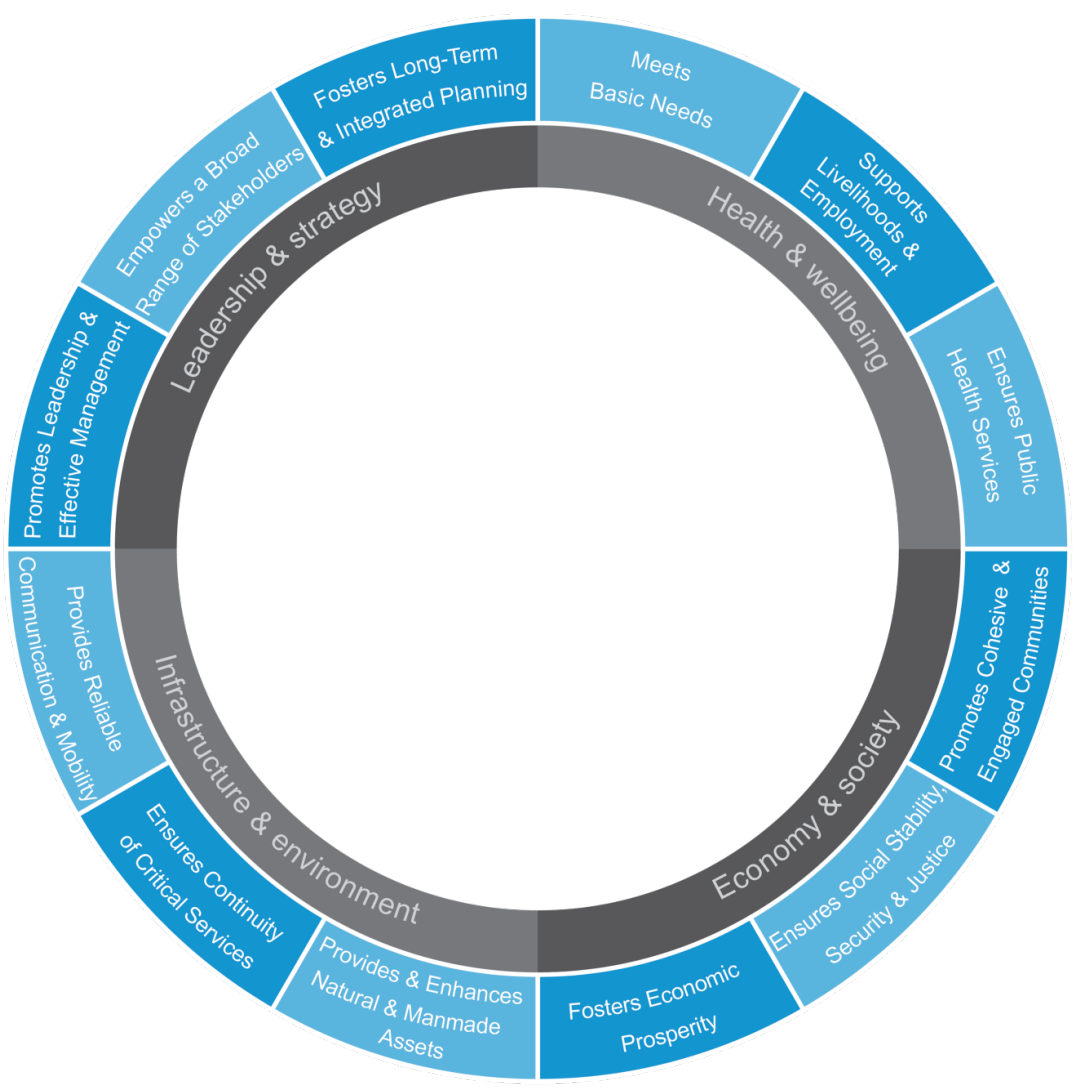

The City Resilience Framework (CRF) wheel that is introduced by 100 Resilient Cities to its city members as a basis to develop the city resilience strategy. 
eTropic 19.2 (2020) Special Issue: Sustainable Tropical Urbanism

\section{Process of Transferring Climate Resilience to Semarang}

The 100RC program works almost identically with all its city members. The program usually begins with an initiation phase. This phase includes the selection of a Chief Resilient Officer (CRO), who leads in establishing the resilience agenda of the city. It also involves the establishment of a representative team of the 100RC. The task of this team is to give everyday assistance to the city in the development of its strategy with additional support from the strategic partners selected by 100RC through a tender process.

The development of the city resilience strategy itself mainly consists of two phases. Phase 1, the Preliminary Resilience Assessment (PRA), aims to discover the shocks and stresses that are experienced by the city and determine priority focus areas and the city's commitment in order to properly formulate the resilience strategy. This step is followed by Phase 2, which is the Formulation of the Resilience Strategy itself. The strategy should identify the priority strategies and actions that will be delivered to achieve the ultimate goal of city resilience. In parallel to these processes, as the participatory mechanism in formulating the resilience strategy several workshops are conducted to gain insights from various stakeholders in the city.

The involvement of Semarang City in this network began in December 2013, at which time Semarang was selected to become one of the first cities in the $100 \mathrm{RC}$ network. A year after the selection, preparation began, and the program was officially started in Semarang in 2015. The 100RC program ran for approximately two years; the Preliminary Resilience Assessment (PRA) phase was undertaken in 2015 and ended with the launch of the Semarang City Resilience Strategy in 2016. The complete process can be viewed in Figure 6 below.

The process of the city resilience strategy in Semarang involved various stakeholders and was coordinated by the 100RC team and a Steering Committee consisting of a strategic partner, the Chief Resilient Officer (CRO) and the Semarang Regional Planning and Development Agency (BAPPEDA). This approach has received criticism from several commentators. 
eTropic 19.2 (2020) Special Issue: Sustainable Tropical Urbanism

Figure 6 Timeline of the 100 Resilient City program in Semarang

\begin{tabular}{|c|c|c|}
\hline \multicolumn{3}{|c|}{100 RC PROGRAM IN SEMARANG } \\
\hline $\begin{array}{c}\text { Initiation Phase } \\
\text { 2013-2015 }\end{array}$ & $\begin{array}{l}\text { Phase 1: } \\
\text { Preliminary Resilience Assessment } \\
\text { (PRA) } \\
2015\end{array}$ & $\begin{array}{l}\text { Phase 2: } \\
\text { Formulation of City Resilience } \\
\text { Strategy } \\
2016\end{array}$ \\
\hline $\begin{array}{l}\text { December } 2013 \\
\text { Semarang was selected as one of } \\
100 R C \text { city members. } \\
\text { December } 2014 \\
\text { Semarang was prepared to execute } \\
\text { the 100RC program. } \\
\text { April - August } 2015 \\
\text { The appointment of Chief Resilience } \\
\text { Officer (CRO), Introduction } \\
\text { workshop to various stakeholders } \\
\text { and establishment of 100RC } \\
\text { Steering Committee consists of } \\
\text { 100RC team, a strategic partner } \\
\text { and BAPPEDA Semarang. }\end{array}$ & $\begin{array}{l}\text { September } 2015 \\
\text { The launch of Preliminary Resilience } \\
\text { Assessment included } 3 \text { themes (Security, } \\
\text { Mobility and Capacity) and } 5 \text { discovery } \\
\text { areas (Basic needs, Employment, } \\
\text { Disasters and diseases, Mobility and } \\
\text { Capacity). } \\
\text { October } 2015 \\
\text { The identification of Discovery Areas. } \\
5 \text { city resilience-working groups were } \\
\text { established to safeguard the process of } \\
\text { strategy formulation. The work resulted in } \\
56 \text { city resilience strategy suggestions and } \\
174 \text { city resilience initiatives. }\end{array}$ & $\begin{array}{l}\text { February } 2016 \\
\text { The identification of opportunities and } \\
\text { priorities of city resilience strategy and } \\
\text { initiatives. } \\
\text { Priority strategy was the result of this } \\
\text { stage, achieved through various } \\
\text { methods. There were } 18 \text { city resilience } \\
\text { strategies and } 53 \text { city resilience } \\
\text { initiatives. } \\
\text { May } 2016 \\
\text { The City Resilience Strategy launch. }\end{array}$ \\
\hline
\end{tabular}

As stated by Leitner et al. (2018), the approach of the 100RC network has an unclear goal in terms of building the resilience of the city. In addition to this criticism, the provided framework does not give instructions as to how these indicators can be fulfilled. Instead of building the capacity of the city to develop its resiliency, a strategic partner (which consists of a group of consultants) prepares the resilience strategy for the city. As a result, city members have a high dependency on the strategic partners assigned by the 100RC.

\section{Case Two: Water as Leverage (WaL)}

\section{Brief Description of the Network}

Water as Leverage (WaL) for Resilient Cities Asia is a program initiated by the Netherlands Enterprise Agency (RVO: Rijkdienst voor Ondernemend Nederland) on behalf of the Ministry of Foreign Affairs. The program's aim is to take up the challenge to solve water-related problems which are occurring due to climate change phenomenon. This initiative was launched in 2017 during the United Nations Climate Change Conference, COP 23, UNFCCC. Differing from the 100RC project, the WaL program focuses its efforts in three selected cities in tropical Asia: Semarang, Indonesia; Chennai, India; and Khulna, Bangladesh (Netherlands Enterprise Agency, 2018). The program ran in parallel in these three cities and aimed to help the selected 
eTropic 19.2 (2020) Special Issue: Sustainable Tropical Urbanism

cities to develop sustainable, bankable and implementable projects as part of the city's commitment to overcoming climate change challenges.

The network also provides each member city with two teams of multidisciplinary experts (consisting of both Dutch and local experts), as well as a mediator to act between the cities, and recourse to both local and international financial institutions that could help the cities to implement projects. Knowledge exchange and capacity building are also part of this network. These activities are done through a series of workshops held in Singapore and locally, to which the city members and assistance teams are invited. By the end of the program, the three selected cities are required to produce a single proposal of quick-win projects that demonstrate the best resiliency approach solutions addressing water-related problems faced by the cities.

\section{What is being Transferred within the Network}

As can be seen from the name of the program itself, Water as Leverage brings a unique proposition to how water-related challenges are viewed. Water is not seen as a "problem", but rather, as a "leverage" that can bring great opportunities and benefits. Within this underlying philosophy, WaL is set up as a program that provides an innovative, inclusive and comprehensive approach to achieve resilient and sustainable development goals through generating necessary investments for bankable, innovative and integral urban water projects that are developed and supported locally. In short, this network introduces a financial point of view to the public sector in the selected cities. The Netherlands Enterprise Agency (RVO), argues that quick-win projects need be of interest to financial institutions or investors to fund and finance the projects as the public sector always has limited resources to contribute to the financing of projects independently. This emphasis on financial feasibility has served as the underlying understanding of each of the WaL selected groups of experts (two expert groups for each of the three cities) and the local stakeholders in developing their end proposals.

\section{Process of Transferring Climate Resilience to Semarang}

The set-up of this network is quite different from the 100RC network. Although the WaL application process is almost identical for the three selected cities, several modifications are introduced based on the individual city's needs. In brief, the program consists of three main parts: preliminary set-up, followed by phase 1 research and phase 2 actions plans. The Preliminary Phase is an open call for groups of multidisciplinary experts (a combination of Dutch and local experts) that have an interest in similar topics, with each city being assisted by two groups of multidisciplinary experts. This step is followed by Phase 1 , in which the groups of 
experts undertake to understand the specific context of the city through research and analysis activities, which will also be used in the development of suitable and feasible projects. At the later Phase 2 stage, the two groups of multidisciplinary experts in collaboration with local stakeholders develop urban project proposals that are bankable, feasible and sustainable. As part of the whole process, the Netherlands Enterprise Agency (RVO), as the initiator, organises local design workshops which take place in the participating city, and regional workshops which take place in Singapore. These sets of workshops are arranged to serve at least two main purposes: (1) an assessment of the deliverables of each group which is undertaken by RVO directly, and (2) knowledge sharing and transfer activities between the group of experts and local stakeholders. Stakeholders from the three cities also learn of success and failure stories from other cities in regards to tackling the challenges.

The involvement of Semarang in the network began in 2018 when two groups of multidisciplinary experts selected by RVO undertook research and analysis of the context of the city's water issues. In this regard, self-organised workshops were facilitated in order to improve understanding of the on-the-ground challenges as well as gain insights into how to prioritise the issues. A year later, in 2019, the groups of experts were in collaboration with Semarang City Government and local stakeholders in order to develop feasible projects focused on water management issues in the city. The commitment and capability of Semarang City Government are two main instruments in prioritising proposed projects as the result of this program. The complete process can be viewed in Figure 7 below.

Figure 7 Timeline of the Water as Leverage Program in Semarang

\begin{tabular}{|c|c|c|}
\hline \multicolumn{3}{|c|}{ WATER AS LEVERAGE (WaL) PROGRAM IN SEMARANG } \\
\hline $\begin{array}{l}\text { Preliminary Phase: } \\
\text { Initiation Phase } \\
\text { 2017-2018 }\end{array}$ & $\begin{array}{l}\text { Phase 1: } \\
\text { Research and Analysis } \\
2018\end{array}$ & $\begin{array}{l}\text { Phase 2: } \\
\text { Formulation of Bankable Projects } \\
\text { Proposal } \\
2019\end{array}$ \\
\hline \multirow[t]{2}{*}{$\begin{array}{l}\text { November } 2017 \\
\text { Initiation of Water as Leverage } \\
\text { program during COP } 23 \text {. } \\
\text { April } 2018 \\
\text { Call for action and recruitment of } \\
\text { groups of experts for the three } \\
\text { selected cities: Semarang } \\
\text { (Indonesia), Chennai (India) and } \\
\text { Khulna (Bangladesh). }\end{array}$} & $\begin{array}{l}\text { September - December } 2018 \\
\text { Two groups of experts in collaboration with } \\
\text { local stakeholders did research and } \\
\text { analysis to discover main challenges of } \\
\text { each cities. } \\
\text { End of } 2018 \\
\text { Each team was gathered in Singapore to } \\
\text { present their results and formulate the next } \\
\text { steps for the Phase } 3 \text {. }\end{array}$ & $\begin{array}{l}\text { January - March } 2019 \\
\text { Two groups of experts in collaboration } \\
\text { with local stakeholders developed and } \\
\text { prioritized projects to be proposed as } \\
\text { solutions upon water-related challenges. } \\
\text { April - May } 2019 \\
\text { The completion of the program and } \\
\text { proposal was launched. }\end{array}$ \\
\hline & $\begin{array}{l}\text { Along with these process, } 2 \text { local workshops and } \\
1 \text { regional workshop were organized: } \\
\text { September \& Early December } 2018 \\
\text { Local workshops in the three cities (organized } \\
\text { consecutively) } \\
\text { December } 2018 \\
\text { Regional workshop in Singapore }\end{array}$ & $\begin{array}{l}\text { Along with these process, } 1 \text { local workshop and } \\
1 \text { regional workshop were organized: } \\
\text { March } 2019 \\
\text { Local workshops in the three cities (organized } \\
\text { consecutively) } \\
\text { April } 2019 \\
\text { Regional workshop in Singapore }\end{array}$ \\
\hline
\end{tabular}


eTropic 19.2 (2020) Special Issue: Sustainable Tropical Urbanism

\section{Analysis}

In order to analyse the policy transfer process as evidenced in the two case studies of 100RC and WaL, this section compiles the data from the in-depth interviews with key actors who engaged in the case studies. Table 1 below organises the data into the four general elements of motivation, content, process and result as previously presented in the conceptual framework for analysing key success factors of the policy transfer process (Figure 2). By considering the distinctive characteristics of 100RC and WaL, this section presents a deductive analysis of the two case studies by using the framework previously presented in Figure 1, and comparing the distinctions between the two case studies below in Table 1 in order to synthesise the key aspects in determining the successfulness factors.

Table 1 Summary of Assessment of Policy Transfer Case Studies

\begin{tabular}{|c|c|c|c|}
\hline \multicolumn{2}{|c|}{$\begin{array}{c}\text { Policy Transfer Analysis } \\
\text { Frameworks }\end{array}$} & \multicolumn{2}{|c|}{ Case Studies Assessment } \\
\hline Elements & Indicators & 100 Resilient Cities (100RC) & Water as Leverage (WaL) \\
\hline \multirow{3}{*}{ Motivation } & $\begin{array}{l}\text { Reason for } \\
\text { doing policy } \\
\text { transfer }\end{array}$ & $\begin{array}{l}\text { Initiated by the policy receiver } \\
\text { (Semarang City Government). } \\
\text { Underwent a selection process by } \\
\text { Rockefeller Foundation to be one of } \\
\text { the } 100 \text { RC city members. }\end{array}$ & $\begin{array}{l}\text { Proposed by the initiator (RVO). } \\
\text { During the preliminary phase, the } \\
\text { initiator did an assessment process } \\
\text { to select the three pilot cities: } \\
\text { Semarang, Chennai, Khulna. }\end{array}$ \\
\hline & $\begin{array}{l}\text { Origin of policy } \\
\text { transfer initiation }\end{array}$ & $\begin{array}{l}\text { Outside/ International Organisation } \\
\text { The method and content of transfer } \\
\text { are initiated by the initiator } \\
\text { (Rockefeller Foundation). }\end{array}$ & $\begin{array}{l}\text { Outside/ International Organisation } \\
\text { The method and content of transfer } \\
\text { are initiated by the initiator (RVO/ } \\
\text { Netherlands Enterprise Agency) }\end{array}$ \\
\hline & $\begin{array}{l}\text { Characteristics } \\
\text { of policy transfer }\end{array}$ & $\begin{array}{l}\text { Voluntary } \\
\text { The city submitted an application to } \\
\text { be part of the 100RC global network. }\end{array}$ & $\begin{array}{l}\text { Mixture (Coercive and Voluntary) } \\
\text { The initiator introduces the program } \\
\text { to the selected cities. Semarang City } \\
\text { Government needs funding to } \\
\text { implement water-related actions } \\
\text { (sited and planned in Semarang } \\
\text { Resilience Strategy). }\end{array}$ \\
\hline \multirow{3}{*}{ Content } & $\begin{array}{l}\text { Type of } \\
\text { information/ } \\
\text { content is being } \\
\text { transferred }\end{array}$ & $\begin{array}{l}\text { Ideology and understanding of the } \\
\text { resilient city, also how to develop a } \\
\text { city resilience strategy. }\end{array}$ & $\begin{array}{l}\text { Ideology and understanding of how } \\
\text { water is seen as "leverage" rather } \\
\text { than a "problem". } \\
\text { The network introduced financial } \\
\text { feasibility of public projects. }\end{array}$ \\
\hline & $\begin{array}{l}\text { The origin of the } \\
\text { transfer content }\end{array}$ & $\begin{array}{l}\text { International organisation: } \\
\text { Rockefeller Foundation and a global } \\
\text { design firm. }\end{array}$ & $\begin{array}{l}\text { International organisation: } \\
\text { RVO. }\end{array}$ \\
\hline & $\begin{array}{l}\text { Transferability of } \\
\text { the content }\end{array}$ & $\begin{array}{l}\text { At the beginning of the involvement, } \\
\text { local stakeholders face a challenge } \\
\text { in understanding the content since } \\
\text { modification is not allowed. }\end{array}$ & $\begin{array}{l}\text { Common understanding of the water- } \\
\text { related issues helps local } \\
\text { stakeholders to easily understand the } \\
\text { content of the transfer. }\end{array}$ \\
\hline Process & $\begin{array}{l}\text { Actors/ } \\
\text { stakeholders }\end{array}$ & $\begin{array}{l}\text { Initiator: } 100 \mathrm{RC} \& \text { Rockefeller } \\
\text { Foundation. }\end{array}$ & $\begin{array}{l}\text { - Initiator: Netherlands Enterprise } \\
\text { Agency (RVO). }\end{array}$ \\
\hline
\end{tabular}


eTropic 19.2 (2020) Special Issue: Sustainable Tropical Urbanism

\begin{tabular}{|c|c|c|c|}
\hline \multicolumn{2}{|c|}{$\begin{array}{l}\text { Policy Transfer Analysis } \\
\text { Frameworks }\end{array}$} & \multicolumn{2}{|c|}{ Case Studies Assessment } \\
\hline Elements & Indicators & 100 Resilient Cities (100RC) & Water as Leverage (WaL) \\
\hline & & $\begin{array}{ll}\text { - } & \text { Transfer Agent: Strategic } \\
& \text { Partner. } \\
\text { - } & \text { Receiver: } 100 R C \text { Steering } \\
& \text { Committee, CRO and } \\
& \text { Semarang City Government. }\end{array}$ & $\begin{array}{l}\text { - Transfer Agent: } 2 \text { Groups of } \\
\text { Multidisciplinary Experts. } \\
\text { - Receiver: Semarang City } \\
\text { Government. }\end{array}$ \\
\hline & Set-up & $\begin{array}{l}\text { A capacity-building process consists } \\
\text { of several steps: } \\
\text { - Establishment of 100RC } \\
\text { Steering Committee led by } \\
\text { CRO (Chief Resilience Officer) } \\
\text { to introduce and secure the } \\
\text { resilience agenda. } \\
\text { - Recruitment of strategic } \\
\text { partners to help the City } \\
\text { Government to develop its } \\
\text { resilience strategy. } \\
\text { - Whole process is done in } 2 \\
\text { years divided into two main } \\
\text { phases: Phase 1: Preliminary } \\
\text { Resilience Assessment (PRA) } \\
\text { and Phase 2: Resilience } \\
\text { Strategy Formulation. }\end{array}$ & $\begin{array}{l}\text { - The set-up resembles a } \\
\text { competition between } 2 \text { groups of } \\
\text { experts to produce project ideas } \\
\text { to be selected into a final } \\
\text { proposal. } \\
\text { - The whole process is done in } \\
\text { less than a year, which is divided } \\
\text { into three main phases: } \\
\text { Preliminary phase, Phase } 1 \\
\text { Research and Analysis of the } \\
\text { City Context and Issues, and } \\
\text { Phase } 2 \text { Formulation of Bankable } \\
\text { Projects. } \\
\text { - Local workshops are done in } \\
\text { each phase, and regional } \\
\text { workshops are organised at the } \\
\text { end of each phase. }\end{array}$ \\
\hline & $\begin{array}{l}\text { Role of actors/ } \\
\text { stakeholders }\end{array}$ & $\begin{array}{l}\text { Initiator establishes a local } \\
\text { committee, recruits CRO and a } \\
\text { strategic partner and supports } \\
\text { the city with necessary } \\
\text { resources, knowledge-sharing } \\
\text { platform, connection with other } \\
\text { city members and technical } \\
\text { assistance. } \\
\text { Transfer agent / strategic } \\
\text { partner helps the city to } \\
\text { develop its resilience strategy } \\
\text { by giving technical assistance } \\
\text { as well as capacity building. } \\
\text { Receivers are in collaboration } \\
\text { with the Strategic Partner to } \\
\text { develop the Resilience } \\
\text { Strategy and its quick-win } \\
\text { actions to be implemented. }\end{array}$ & $\begin{array}{l}\text { - Initiator recruits two groups of } \\
\text { experts in each city and } \\
\text { organises local and regional } \\
\text { workshops as part of the } \\
\text { knowledge exchange platform. } \\
\text { - Transfer agents/groups of } \\
\text { experts help the city to formulate } \\
\text { and prioritise the projects. } \\
\text { - Receivers are in collaboration } \\
\text { with the groups of experts to } \\
\text { develop projects as well as } \\
\text { integrate, adapt and adopt them } \\
\text { into the city planning mechanism. }\end{array}$ \\
\hline & $\begin{array}{l}\text { Stakeholders } \\
\text { engagement }\end{array}$ & $\begin{array}{l}\text { 100RC provides opportunities } \\
\text { for building the city's capacity } \\
\text { by connecting them with other } \\
\text { cities through the various } \\
\text { platforms: conferences, study } \\
\text { tours, online courses, etc. } \\
\text { Strategic partner and 100RC } \\
\text { Steering Committee acts as a } \\
\text { mediator between the Initiator } \\
\text { \& City Government in order to } \\
\text { avoid impasse in the process. }\end{array}$ & $\begin{array}{l}\text { - There is a sense of competition } \\
\text { between } 2 \text { groups of experts that } \\
\text { triggers unintegrated results and } \\
\text { overlapping efforts during the } \\
\text { process. } \\
\text { - Due to the competitive } \\
\text { atmosphere, there is a lack of } \\
\text { coordination between the two } \\
\text { groups of experts. }\end{array}$ \\
\hline
\end{tabular}


eTropic 19.2 (2020) Special Issue: Sustainable Tropical Urbanism

\begin{tabular}{|c|c|c|c|}
\hline \multicolumn{2}{|c|}{$\begin{array}{l}\text { Policy Transfer Analysis } \\
\text { Frameworks }\end{array}$} & \multicolumn{2}{|c|}{ Case Studies Assessment } \\
\hline Elements & Indicators & 100 Resilient Cities (100RC) & Water as Leverage (WaL) \\
\hline & $\begin{array}{l}\text { Enabling } \\
\text { conditions }\end{array}$ & $\begin{array}{l}\text { - Semarang good governance. } \\
\text { Good international } \\
\text { collaboration portfolio in the } \\
\text { previous almost similar } \\
\text { initiative (ACCCRN). } \\
\text { - The shared understanding of } \\
\text { the issues among local } \\
\text { stakeholders. } \\
\text { The presence of an } \\
\text { educational institution (UNDIP) } \\
\text { as part of the 100RC Steering } \\
\text { Committee to support the city } \\
\text { government. } \\
\text { The establishment of the } \\
\text { Strategic Partner and Steering } \\
\text { Committee based in Semarang } \\
\text { to guard the process and } \\
\text { agenda of a resilient city. }\end{array}$ & $\begin{array}{l}\text { - Good previous international } \\
\text { collaboration (e.g. Banger } \\
\text { Polder). } \\
\text { - The city government's consistent } \\
\text { commitment to solving urban } \\
\text { challenges. } \\
\text { - Semarang good governance. } \\
\text { - Solid collaboration and network } \\
\text { of local stakeholders to support } \\
\text { the city's programs. }\end{array}$ \\
\hline & $\begin{array}{l}\text { Constrained } \\
\text { conditions }\end{array}$ & $\begin{array}{l}\text { - Fast rotation inside the } \\
\text { government body. } \\
\text { - } \quad \text { "Silo" working culture. } \\
\text { - The shift of CRO during the } \\
\text { process. } \\
\text { - Language barriers between } \\
\text { local and international actors. }\end{array}$ & $\begin{array}{l}\text { - Distant interactions between } \\
\text { Initiator, Transfer Agents and } \\
\text { Receiver. } \\
\text { - High dependency on the } \\
\text { Transfer Agents and Initiator. } \\
\text { - Lack of mutual interactions } \\
\text { between two groups of experts. } \\
\text { - Lack of government's willingness } \\
\text { to take the lead in the process. } \\
\text { - Absence of a body/institution } \\
\text { which assists the City } \\
\text { Government to continue the } \\
\text { agenda. }\end{array}$ \\
\hline & Duration & Two years & 9-14 months \\
\hline \multirow{3}{*}{ Result } & Final product & $\begin{array}{l}\text { Semarang City Resilience Strategy } \\
\text { (including its action plans) }\end{array}$ & $\begin{array}{l}\text { (Bankable) Urban water-related } \\
\text { projects proposal }\end{array}$ \\
\hline & $\begin{array}{l}\text { Further/ follow- } \\
\text { up process }\end{array}$ & $\begin{array}{ll}\text { - } & \text { Better disaster management at } \\
\text { neighbourhood levels. } \\
\text { - } & \text { Semarang-Toyama city } \\
& \text { cooperation in building Bus } \\
& \text { Rapid Transit (BRT) system. } \\
\text { - } & \text { Adoption of actions into urban } \\
\text { development plan and } \\
\text { strategy. } \\
\text { - Semarang is awarded most } \\
\text { innovative city by the National- } \\
\text { Planning and Development } \\
\text { Agency (BAPPENAS). }\end{array}$ & $\begin{array}{l}\text { - Integrated coastal zone } \\
\text { management with the regional } \\
\text { government. } \\
\text { The increasing awareness in } \\
\text { finding alternative funding } \\
\text { solutions. } \\
\text { - As a trigger for the City } \\
\text { Government to find alternative } \\
\text { funding through private CSR } \\
\text { (Corporate Social Responsibility) } \\
\text { mechanism. }\end{array}$ \\
\hline & $\begin{array}{l}\text { Degree of } \\
\text { transfer }\end{array}$ & Mixture of Emulation and Inspiration & "Copying" \\
\hline
\end{tabular}


eTropic 19.2 (2020) Special Issue: Sustainable Tropical Urbanism

\section{Motivation for Transfer}

In terms of the first key success factor of the policy transfer process, the motivation of transfer, the two case studies show very distinct results due to the differences in the initiation mechanism of the two global networks. In 100RC, Semarang City Government submitted an application to be part of the 100RC network. Rockefeller Foundation, as the initiator, then selected the cities to be part of the network based on several selection criteria. Semarang as a previous partner in the Rockefeller's Asian Cities Climate Change Resilience Network (ACCCRN) was chosen as one of 32 cities worldwide in the first phase (Lassa, J.A., 2019). This shows that the involvement of Semarang is voluntary as Semarang City Government willing applied to join the network and went through the selection process organised by the initiator.

On the other hand, the involvement of Semarang in the WaL program presents a contrary result. RVO, as the initiator, undertook a preliminary study to choose three pilot cities in Asia to kick start the initiative. Based on the preliminary study, Semarang in Indonesia, Chennai in India, and Khulna in Bangladesh were selected, and the initiator introduced the network to the local stakeholders in the three selected cities. The implementation of this program in Semarang is also part of the bilateral agreement between Indonesia and the Netherlands in terms of water management aid for Indonesia. The offer from RVO for Semarang to join the network happened at the right moment. Semarang had published its resilience strategy, however, the city was lacking funding to finance the strategy's stated water-related action plans. Semarang City Government believed that the involvement of the city in this network could help to strengthen the action plans and find an alternative source of funding from an international partner. In short, the characteristic of the transfer is a mixture between coercive and voluntary, since both parties (Initiator and Receiver) are complementary to each other.

Reflecting on the result of each of the policy transfers, 100RC was able to establish a long-lasting working group dedicated to representing its contents due to the voluntary self-generated motivation by the local stakeholders that was further supported and funded by the initiator. The WaL program experienced relatively little in the way of constraints during the transfer process because the coercive pressure from the initiator is supported by the resources available for pitching purposes, such as ideas to the local government and for financial support to the international bank. Voluntary participation by the receiver to engage in pitching for funding determines the continuity of the process, hence this pertains to analytical observations (Stead, 2012) regarding the importance of voluntary initiation by the receiver in the policy transfer. 
eTropic 19.2 (2020) Special Issue: Sustainable Tropical Urbanism

\section{Content of Transfer}

During the process of transfer 100RC's City Resilience Framework (CRF) serves as the basis for all member cities to develop their city resilience strategy and does not allow the member cities to modify the content based on their city's need. It derives from the 100RC understanding of how a resilient city should look, in which all of the urban aspects are treated equally to create the city's resiliency. Along with this process, $100 \mathrm{RC}$ also requires its city members to adapt and adopt this way of thinking or approach into the existing system and acts as the ideal resilience system. The content framework itself is created by the Initiator (Rockefeller Foundation) in consultation with a global design firm who undertook a practical design approach (applicable to all cities), despite the unique characteristics and distinctive challenges of each member city in building its resilience. In the case of Semarang, the City Government and local stakeholders took some time to understand the content of transfer brought by the initiator. Due to the top-down nature of its content, this process faced a tremendous challenge at the beginning due to a language barrier issues of comprehension between the Initiator, Transfer Agent and Receiver. The Transfer Agent had to translate the CRF into Indonesian in order for local stakeholders to easily and fully grasp the content.

In contrast, WaL's content was easy to understand by the local stakeholders in Semarang because it highlights the common issue of water faced by the city. Local stakeholders have perfectly understood the situation. Furthermore, RVO, the initiator of the WaL program, also introduced an innovative aspect to the way of thinking for the public sector in formulating its projects or programs. Bankability, or the ability for the projects to be funded by financial institutions, is something that is highlighted and elevated during the transfer process. This school of thought was relatively new to the local stakeholders, since the City Government had previously depended on the regional public budget to implement its plans, projects and programs. Creative financing capacity was thus introduced to local stakeholders by synthesising processes for pitching for international funds with the urban design provided by the network. As part of this process, the initiator also undertakes a match-making process between the project ideas and possible funders or investors to turn the ideas into pilot projects.

Content-wise, WaL, which mostly consists of urban planners, designers, and scholars provides a well-designed proposal consisting of contextualised climate change issues faced by the city and its responding urban strategies that are easily comprehended by the local stakeholders. It transfers the ideas to the city's board of planning with the help of local urbanisation scholars in order to eliminate the potential language barrier in the demonstration of policy transfers. In comparison, the 100RC supply a well- 
eTropic 19.2 (2020) Special Issue: Sustainable Tropical Urbanism

detailed narrative in which the adaptation into city policies, projects, and programs requires an intensive team formation which employs workshops, capacity building, and technical assistance to articulate the contents into policy adoption by the city (Lassa, J. 2019).

\section{Process of Transfer}

The process of transfer in the two case studies also happens under the influence of two different set-ups. The process of transfer can be analysed by examining indicators, such as: who is involved during the process, the set-up of the network, the engagement of the stakeholders, and the timeline. In the 100RC network, there was always a committee situated in each member city led by a CRO (Chief Resilience Officer) who would act as the Transfer Agent to help city members during the process of transfer. This transfer agent maintains daily communication with various local stakeholders in the city. Meanwhile, a Strategic Partner is also hired to help the Transfer Agent in terms of technical assistance in developing the resilience strategy, so the strategy could be effectively performed. Workshops and capacity building sessions are carried out, custom-based on the needs of the city. 100RC organised and provided a platform for each member city to connect with other member cities globally. This flexibility was helped by the long duration provided by the program, which spanned two years.

On the other hand, the WaL process resembled a design competition project. Two groups of multidisciplinary experts were recruited to each city to help the city to develop its bankable project proposals. However, during the process the Initiator, RVO, did not undertake to help the two groups of experts to connect with the local stakeholders, each group being left to make its own efforts to connect and communicate with local stakeholders. The process was even more challenging due to the distance between the two groups of experts, as the Transfer Agent was mainly situated in the Netherlands, while the receiver was located in Indonesia. In short, the lack of institutional pathways and coordination maintenance between the policy experts and the receiver constrained the policy transfer process.

Engagement of local strategic stakeholders such as local experts, universities, and related public institutions by both programs played an important role in the carrying out of successful transfers. Various enabling factors came from the good connection between the initiator and receiver stakeholders: an established group of experts, trustworthy action from previous cooperation, and institutional support from the city government. However, any factors that minimised the harmony between collaborators would grow into a constraint on the process itself: a language barrier, distance 
eTropic 19.2 (2020) Special Issue: Sustainable Tropical Urbanism

between actors, and the absence of local institutionalised groups that specifically organise the whole transfer process.

\section{Result of Transfer}

The two case studies also show two distinctive outputs. During the involvement of Semarang City Government in the 100RC network, the city produced various Resilience Strategies: neighbourhood level disaster management programs, creation of a bus rapid transportation route, and the adoption of the policy into the city's short and mid-term development plans. Meanwhile, WaL assisted Semarang City in producing climate-related project proposals that are feasible and bankable and which can facilitate the procurement of further international funds and investments in the city's programs. These proposed projects are mainly technical interventions that emphasise strong spatial planning and environmental engineering as solutions in response to climate change.

The results section indicates that the 100RC program degree of transfer during the process shows a combination between emulation and inspiration, since Semarang City Government could develop action plans that are suitable within its capability and needs and the City Resilience Framework (CRF) only serves as a basis for how to organise and prioritise the action plans. In contrast, this does not happen in the WaL process as the project proposals are mainly created by the two groups of experts and the Transfer Agents. Thus, the projects and methodologies are primarily copied from practices in the Netherlands as the country origin of the transfer. Even though the project proposals that resulted during the WaL process are easy to adapt and adopt within the existing planning mechanism in Semarang City, the absence of an institutionalised body for local stakeholders that can carry forward the agenda might hinder the consistency of further project implementations and policy adoption.

\section{Conclusion and Discussion}

The policy transfer process is common in contemporary policy making. It refers to the process of transferring policies applied in one time and location to those in a different location and time. This practice is also found in the process of cities sharing solutions and innovations to cope with climate-related challenges. As cities around the world and cities located in specific climatic and geographic zones of the world such as the tropics - face similar climate change challenges (Harding et al., 2016), these cities are also searching for climate resilience solutions and programs. As it is crucial for cities to learn from each other in order to develop greater climate-resilience, the policy transfer process has become an important component in the development of climate resilience. However, the policy transfer process is complex and at high risk of 
eTropic 19.2 (2020) Special Issue: Sustainable Tropical Urbanism

encountering an impasse, and thus failing. Departing from the literature that analyses policy transfer failure, this paper seeks to articulate and analyse factors that determine successful policy transfer processes by using two case studies of climate resilience programs as they unfolded in Semarang City, Indonesia.

In the case of climate resilience programs, a successful policy transfer process is indicated by the existence of adaptation or adoption of the content of transfer from the planning mechanism to the receiver city. In the Theoretical Framework section of this paper, four main elements were identified as the success factors of a policy transfer process. These four main elements are motivation, the content of transfer, transfer process and the result of the transfer. In order to further analyse the performance of each element, this research paper undertook a field study to assess the performance of each element and how it would determine the successfulness of transferring policies and programs that can address global-scale issues.

An intensive assessment of the policy transfer processes of the two case studies, 100 Resilient Cities (100RC) and Water as Leverage (WaL) programs in Semarang City, reveals at least four lessons learned. 1. Voluntary motivation from the receiver ensures the sustainability of the policy transfer process. This motivation acts as a sole driver of continuity of the process and leads to further policy making and action planning processes. This can be seen in the first case study, the involvement of Semarang in the 100RC network, where the commitments written within the Semarang Resilient Strategy are consistently implemented by the Semarang City Government. Unfortunately, this does not occur in the second, case study, WaL, which was initiated by the foreign partner. 2 . The technical feasibility and its localised policies determine the difficulty of the policy transfer process. While 100RC provided a massive number of detailed strategies and policies, WaL focused on problem-solving through urban planning that could be directly adopted by the respective stakeholders in the government body. 3. The existence of local strategic partners remains crucial for a successful policy transfer process. Local strategic partners act as a transfer agent who provides mediation, technical assistance, and maintains the continuity of the policy transfer process, even after the aid program has ended. This lesson is derived from the experience of the first case study where the 100RC Steering Committee led by a Chief Resilience Officer (CRO) acts as a transfer agent to initiate the resilience agenda in the city and guard the process. This kind of arrangement is absent in the second WaL case study, which leads to discontinuity in the transfer process. In other words, distance between the transfer agent and the receiver negatively impacts the policy transfer process' effectiveness or success. 4 . The policy transfer process is a process of transformation, including in ways of thinking, planning customs and problemsolving. Such transformations are not possible under short time constraints, thus duration and continuity play an important role in policy transfer processes. The first 
eTropic 19.2 (2020) Special Issue: Sustainable Tropical Urbanism

case study, 100RC, is proven more successful than the second WaL case study in terms of duration.

In conclusion, by using the assessment framework developed in this research paper, we can determine that the first case study overall provided a more successful policy transfer process. However, it should be remembered that the successful process that happened in Semarang City cannot be separated from the preconditions of the policy transfer process, which was determined by the city itself. These preconditions include: good international portfolios, good governance, solid local stakeholders' collaboration, and shared understanding regarding issues and challenges. It is recommended that the four lessons learned, as well as an understanding of the preconditions of the receiver city, should be taken into consideration before undertaking any policy transfer process in order to better ensure the success of the process. 
eTropic 19.2 (2020) Special Issue: Sustainable Tropical Urbanism

\section{References}

100 Resilient Cities. (2016). Resilient Semarang: Moving Together Towards a Resilient Semarang. Semarang: 100 Resilient Cities.

100 Resilient Cities. (2019). 100 Resilient Cities: About Us. Retrieved from 100 Resilient Cities: https://www.100resilientcities.org/about-us/

Amni, Z. R., \& Diyah, N. (2018). Triple Helix in the Poverty Reduction Policy Based on Community Empowerment in Semarang City. Paper presented at the E3S Web of Conferences.

Benson, D., \& Jordan, A. (2012). Policy transfer research: still evolving, not yet through? Political studies review, 10(3), 333-338. https://doi.org/10.1111/j.14789302.2012.00273.x

Central Bureau of Statistics. (2018). Kota Semarang dalam Angka. Semarang, Central Java, Indonesia: Central Bureau of Statistics.

Datta, A., Jones, H., Febriany, V., Harris, D., Dewi, R. K., Wild, L., \& Young, J. (2011). The political economy of policy making in Indonesia: Opportunities for improving the demand for and use of knowledge. Overseas Development Institute (ODI). Working Paper 340. https://www.odi.org/sites/odi.org.uk/files/odi-assets/publications-opinionfiles/7531.pdf

De Villiers, J., De Coning, T., \& Smit, E. (2007). Towards an understanding of the success factors in international twinning and sister-city relationships. South African Journal of Business Management, 38(1), 1-10. https://hdl.handle.net/10520/EJC22328

Dolowitz, D., \& Marsh, D. (1996). Who Learns What from Whom: a Review of the Policy Transfer Literature. Political Studies, 343-357. https://doi.org/10.1111/j.14679248.1996.tb00334.x

Dolowitz, D. P., \& Marsh, D. (2000). Learning from abroad: The role of policy transfer in contemporary policy making. Governance, 13(1), 5-23. https://doi.org/10.1111/09521895.00121

Griggs, D., Stafford-Smith, M., Gaffney, O., Rockström, J., Öhman, M. C., Shyamsundar, P., Steffen, W., Glaser, G., Kanie, N., \& Noble, I. (2013). Sustainable development goals for people and planet. Nature, 495(7441), 305-307. https://doi.org/10.1038/495305a

Harding, S., Bird, G., Losos, E., Aderolili, R., \& Hotez, P. (2016). International Day of the Tropics: Towards a better global future. eTropic: electronic journal of studies in the tropics 15 (2), 5-12. https://doi.org/10.25120/etropic.15.2.2016.3538

Harwitasari, D., \& van Ast, J. A. (2011). Climate change adaptation in practice: people's responses to tidal Flooding in Semarang, Indonesia. Journal of Flood Risk Management, 1-18. https://doi.org/10.1111/j.1753-318X.2011.01104.x

Hasyim, F., Subagio, H., \& Darmawan, M. (2016). One map policy (OMP) implementation strategy to accelerate mapping of regional spatial planing (RTRW) in Indonesia. Paper presented at the 8th IGRSM International Conference and Exhibition on Remote Sensing \& GIS, Kuala Lumpur, Malaysia. IOP Conf. Series: Earth and Environmental Science.

Lassa, J. (2019). When does institutionalization mean NGOnization? Sustaining Climate Risk Governance in Secondary Cities. https://www.rdi.or.id/storage/files/publication/89.pdf

Lassa, J. A. (2019). Negotiating institutional pathways for sustaining climate change resilience and risk governance in Indonesia. Climate, 7(8), 95. https://doi.org/10.3390/cli7080095

Leitner, H., Sheppard, E., Webber, S., \& Colven, E. (2018). Globalizing Urban Resilience. Urban Geography, 39 (8), 1276-1284. https://doi.org/10.1080/02723638.2018.1446870 
eTropic 19.2 (2020) Special Issue: Sustainable Tropical Urbanism

Lundberg, A. (2020). Balinese Dancer wearing a Gas Mask: Climate Change and the Tropical Imaginary. [COP26 Perspectives Special Issue]. Scottish Geographical Journal RSGJ. 136 (1-4). https://doi.org/10.1080/14702541.2020.1858589

Marfai, M. A., \& King, L. (2008). Coastal flood management in Semarang, Indonesia. Environmental Geology, 55, 1507-1518. https://doi.org/10.1007/s00254-007-1101-3

McCann, E., \& Ward, K. (2012). Policy Assemblages, Mobilities and Mutations: Toward a Multidisciplinary Conversation. Political Studies Review, 10, (3), 325-332. https://doi.org/10.1111/j.1478-9302.2012.00276.x

Mertz, O., Halsnæs, K., Olesen, J. E., \& Rasmussen, K. (2009). Adaptation to climate change in developing countries. Environmental management, 43, 743-752. https://doi.org/10.1007/s00267-008-9259-3

Minkman, E., Letitre, P., \& van Buuren, A. (2019). Reconstructing the impasse in the transfer of delta plans: evaluating the translation of Dutch water management strategies to Jakarta, Indonesia. Journal of Environmental Planning and Management, 62 (9), 1562-1582 . https://doi.org/10.1080/09640568.2018.1527216

Nugroho, P., \& Sugiri, A. (2009). Studi Kebijakan Pembangunan Terhadap Perubahan Tata Ruang Di Kota Semarang. Jurnal Riptek, 3(2), 41-51. https://bappeda.semarangkota.go.id/uploaded/publikasi/Studi Kebijakan Pembangu nan Terhadap Perubahan Tata Ruang Di Kota Semarang PRIHADI. N dan AGUNG. S.pdf

Peters, R. (2012). Factors that contribute to effective Dutch-funded international water projects: A case study: Banger Pilot Polder Project in Semarang, Indonesia. [Unpublished Thesis]. University of Twente. http://essay.utwente.nl/61728/

Republik Indonesia. (2004). Undang-Undang Republik Indonesia Nomor 25 Tahun 2004 Tentang Sistem Perencanaan Pembangunan Nasional.

Stead, D. (2012). Best practices and policy transfer in spatial planning. Planning Practice and Research, 27(1), 103-116. https://doi.org/10.1080/02697459.2011.644084

Stone, D. (2001). Learning lessons, policy transfer and the international diffusion of policy ideas. Centre for the Study of Globalisation and Regionalization working paper (69/01). University of Warwick. https://warwick.ac.uk/fac/soc/pais/research/researchcentres/csgr/papers/workingpap ers/2001/wp6901.pdf

Stone, D. (2004). Transfer agents and global networks in the 'transnationalization' of policy. Journal of European public policy, 11(3), 545-566. https://doi.org/10.1080/13501760410001694291

Sutarto, R., \& Jarvie, J. (2012). Integrating climate resilience strategy into city planning in Semarang, Indonesia. Climate Resilience Working Paper No. 2 ISET-International.

The Netherlands Enterprise Agency. (2018). Water as Leverage for Resilient Cities Asia: Call for Action. The Hague: The Netherlands Enterprise Agency.

Vettoretto, L. (2009). A Preliminary Critique of the Best and Good Practices Approach in European Spatial Planning and Policy-making. European Planning Studies, 17 (7), 1067-1083. https://doi.org/10.1080/09654310902949620

Wright, C., \& Nyberg, D. (2017). An inconvenient truth: How organizations translate climate change into business as usual. Academy of Management Journal, 60(5), 1633-1661. https://doi.org/10.5465/ami.2015.0718 


\section{Acknowledgements}

The authors would like to thank all the people who have contributed during this study and who have given their time and help to produce and to strengthen this paper.

Yulia Yulia (B.Arch., M.Sc. UMD), is an urban planner and designer with interests in several topics pertaining to urban development, including: sustainable development, climate resilience, historical urban landscape and urban strategic planning. She has experience working with multicultural teams both in developed and developing countries. Yulia is currently working as an urban planner based in Jakarta, Indonesia, and is active in several local and international affiliations, which focus on climate action and implementing good practices towards liveable cities, such as: IDN Liveable Cities and United Nations Planners for Climate Action (UN-P4CA).

Reza Arlianda (B. Arch., M.Sc), is an architect and program manager in the Sokola Institute which advocates for the indigenous community of Orang Rimba (People of the Forest) Sumatra. Having an urban studies background from Delft Technology University (TU Delft), the Netherlands, he has a strong research interest regarding participatory development, informal settlements, and inclusive cities. He is affiliated with IDN Liveable Cities within the project of Water as Leverage Semarang and holds responsible as social engagement facilitator through socio-economic studies, Building with People program, and community discussion with local stakeholders across various platforms in Semarang. 